\title{
Immunity and AAV-mediated gene therapy for muscular dystrophies in large animal models and human trials
}

\author{
' Division of Clinical Research, Fred Hutchinson Cancer Research Center, Seattle, WA, USA \\ ${ }^{2}$ Department of Medicine, University of Washington, Seattle, WA, USA \\ ${ }^{3}$ Division of Human Biology, Fred Hutchinson Cancer Research Center, Seattle, WA, USA \\ ${ }^{4}$ Department of Neurology, University of Washington, Seattle, WA, USA \\ ${ }^{5}$ Department of Biochemistry, University of Washington, Seattle, WA, USA
}

Zejing Wang ${ }^{1,2}$, Stephen J. Tapscott ${ }^{2,3,4}$, Jeffrey S. Chamberlain ${ }^{3,4,5}$ and Rainer Storb ${ }^{1,2}$

\section{Edited by:}

Hildegund C. J. Ertl, Wistar Institute, USA

\section{Reviewed by:}

Roland W. Herzog, University of

Florida, USA

Valder Arruda, University of

Pennsylvania and The Children's

Hospital of Philadelphia, USA

\section{*Correspondence:}

Zejing Wang, Transplantation Biology

Program, Division of Clinical

Research, Fred Hutchinson Cancer

Research Center, 1100 Fairview

Avenue N, D1-100, Seattle, WA

98109-1024, USA.

e-mail: zwang@fhcrc.org
Adeno-associated viral (AAV) vector-mediated gene replacement for the treatment of muscular dystrophy represents a promising therapeutic strategy in modern medicine. One major obstacle in using AAV vectors for in vivo gene delivery is the development of host immune responses to the viral capsid protein and transgene products as evidenced in animal models and human trials for a range of genetic diseases. Here, we review immunity against AAV vector and transgene in the context of gene delivery specific to muscles for treating muscular dystrophies and non-muscle diseases in large animal models and human trials, factors that influence the intensity of the immune responses, and immune modulatory strategies to prevent unwanted immune responses and induce tolerance to the vector and therapeutic gene for a successful gene therapy.

Keywords: AAV, immunity, muscular dystrophy, immune modulation, review

\section{INTRODUCTION}

Muscular dystrophies are a group of heterogeneous diseases that primarily affect striated muscles throughout the body. Many of these myopathies are caused by mutations in genes that encode structural proteins which link the cytoskeleton of muscle fibers to the extracellular matrix. The absence of functional proteins results in destabilization of the muscle membrane, increased muscle fragility and degeneration, and progressive muscle wasting, all of which compromise the patients' mobility and, in the severe disease forms (Emery, 2002) such as Duchenne muscular dystrophy (DMD), lead to death.

Over the past decades, viral vector-mediated gene replacement has evolved as an attractive treatment strategy. Studies focusing on adenoviral (Ad), retroviral, and adeno-associated viral (AAV) vectors have shown that delivery via these vectors of full-length or truncated but functional genes improves the disease phenotype in animal models (Gregorevic and Chamberlain, 2003; Dudley et al., 2004; Gregorevic et al., 2004; Li et al., 2005; Liu et al., 2005), which has led to initiation of early phase clinical trials (Mendell et al., 2009, 2010a). However, a major obstacle identified from preclinical and clinical studies is the host immune response to the viral capsid protein and the therapeutic transgene product, which may limit the efficacy or efficiency of this approach.

This review will focus on recent reports of immunity to AAV capsid proteins and transgene products in large animal models and human trials of muscular dystrophy (summarized in the Table 1), as well as strategies that are needed for a successful in vivo gene transfer to muscle.

\section{IMMUNITY TO AAV AND TRANSGENE WHEN DELIVERED TO MUSCLE INTRAMUSCULAR INJECTION OF AAV}

Administration of $A A V$ vectors to skeletal muscle via direct intramuscular injection has been the most common route utilized for gene delivery while developing treatments for the muscular dystrophies. While fairly promising safety profiles were reported in mouse models, cytotoxic $\mathrm{T}$ cell responses to AAV vector and transgene product in muscle of large animal models have been reported recently. In immunocompetent dogs, we reported that local intramuscular injection of AAV2 or AAV6 vectors in wild type or DMD dogs induced robust $\mathrm{T}$ cell-mediated immune responses against AAV capsid proteins that peaked 4 weeks after vector injection and eliminated much of the transgene expression by week 10 (Wang et al., 2007a). The immune responses were triggered regardless of the nature of the transgene delivered or the vector purification methods. Yuasa et al. (2007) reported that injection of AAV2 evoked strong inflammatory responses to transgene products in dog muscles. Robust cellular infiltration was also reported by Yue et al. (2008) when AAV9 vectors were injected into muscles of normal adult dogs, but not in muscles of neonatal dogs.

The binding ability of AAV capsids to heparan sulfate proteoglycans (HSPG) was suggested to facilitate the uptake of certain $\mathrm{AAV}$ serotypes, such as AAV2, by dendritic cells (DC), which leads to antigen processing, MHC class I antigen presentation, and a consequent cell-mediated cytotoxic $\mathrm{T}$ cell responses (Vandenberghe et al., 2006). However, this notion has not been confirmed in large animal or humans. Studies by Takeda's group (Ohshima et al., 2009) demonstrated that cellular immune responses were 
Table 1 | Summary of studies using AAV gene transfer to muscle.




Table 1 | Continued

\begin{tabular}{|c|c|c|c|c|c|c|}
\hline Disease model & $\begin{array}{l}\text { Species in } \\
\text { study }\end{array}$ & $\begin{array}{l}\text { Transgene } \\
\text { product }\end{array}$ & $\begin{array}{l}\text { Serotype } \\
\text { (route of injection) }\end{array}$ & Drugs (regimen) & $\begin{array}{l}\text { Immune } \\
\text { responses }\end{array}$ & $\begin{array}{l}\text { Transgene } \\
\text { expression }\end{array}$ \\
\hline $\begin{array}{l}\text { HB (Manno et al., } \\
\text { 2003) }\end{array}$ & Human trials & hu-cFIX & AAV2 (IM) & None & - & 10 mos \\
\hline $\begin{array}{l}\text { LPL (Mingozzi } \\
\text { et al., 2009) }\end{array}$ & Human & LPL & AAV1 (IM) & None & + & $6 \mathrm{mos}$ \\
\hline $\begin{array}{l}\text { AAT (Brantly et al., } \\
\text { 2009) }\end{array}$ & Human & AAT & AAV1 (IM) & None & + & $\sim 12$ mos \\
\hline $\begin{array}{l}\text { AAT (Flotte et al., } \\
\text { 2011) }\end{array}$ & Human & AAT & AAV1 (IM) & None & + & $>3$ mos \\
\hline
\end{tabular}

ATG, anti-thymocyte globulin; AAT, alpha-1 antitrypsin; $\beta$-gal, $\beta$-galactosidase; cFIX, canine factor IX; cmEpo, cynomolgus macaque erythropoietin; CSP, cyclosporine; DMD, Duchenne muscular dystrophy; HB, hemophilia B; hu, human; IM, intramuscular; i.v., Intravascular; K9, canine; LGMD, limb-girdle muscular dystrophy; LPL, lipoprotein lipase; MMF, mycophenolate mofetil; NHP, non-human primate; pts, patients; PLAP, placenta alkaline phosphates; rtTA, reverse tetracycline transactivator; WT, wild type, + , positive for either humoral or cellular or both immune responses.; \pm , limited humoral or cellular responses.

elicited in dog muscles transduced with either AAV2 or AAV8, a non-HSPG binding serotype. The immune responses can be induced by both the vector capsid protein and the transgene product. Nevertheless, the authors documented less inflammation by histological analysis following intramuscular injection of AAV8$\beta$-galactosidase compared to AAV2- $\beta$-galactosidase into dog muscle, and AAV8- $\beta$-galactosidase expression did not last for more than 4 weeks (Ohshima et al., 2009). AAV1, another serotype that does not bind HSPG, also induced significant cellular immune responses when injected into dog muscles (Wang et al., 2010).

In humans, a phase I clinical trial of limb-girdle muscular dystrophy (LMGD-2D; Mendell et al., 2009) reported both humoral (in all three patients seen as early as 2 weeks) and cellular immunity (in one patient detected from weeks 2 to 12) to AAV1 capsids following intramuscular injection of $3.25 \times 10^{11} \mathrm{vg} / \mathrm{site}$, though the immune response did not diminish transgene expression. However, the data are difficult to interpret because of the use of (1) a 3-day course of methylprednisolone (from day of injection to day 2) in all patients; and (2) the extensor digitorum brevis muscle which is generally spared from the dystrophic process, hence dose not display pre-existing and ongoing inflammation, which is characteristic of dystrophic muscle. The use of a muscle specific promoter may also contribute to the lessened immune responses. In a follow-up paper by Mendell et al. (2010b), two out of three patients had sustained transgene expression at 6 months, and humoral and $\mathrm{T}$ cell responses to AAV1 were detected in the patient failed to show expression. Herson et al. (2011) reported modest cellular infiltration at week 4 following injection of $4.5 \times 10^{10} \mathrm{vg} / \mathrm{site}$ of AAV1, but not after a lower dose of $3 \times 10^{9} \mathrm{vg} / \mathrm{site}$, into muscle of LGMD patients with transgene expression being detected in limited muscle fibers (4.7-10.5\%). A recent phase I trial on DMD from Mendell et al. (2010a) also raised the potential of cellular immune responses to either self or non-self dystrophin epitopes. In the study, AAV vectors carrying a truncated but functional dystrophin gene were delivered intramuscularly into DMD patients. None of the patients displayed mini-dystrophin gene expressing myofibers at the two muscle biopsy time points, days 42 and 90 . Four out of six patients had detectable dystrophin-specific $\mathrm{T}$ cells, including $\mathrm{CD} 4^{+}$and $\mathrm{CD} 8^{+}$
T cells, in peripheral blood, with two patients having dystrophinspecific $\mathrm{T}$ cells before vector treatment. In contrast, immune responses to AAV capsid were not reported. The authors suggested that $\mathrm{T}$ cells targeting self or non-self dystrophin epitopes may have eliminated mini-dystrophin expressing muscle fibers in the study.

\section{INTRAVASCULAR ADMINISTRATION OF AAV TO MUSCLES}

Administration of AAV vectors to skeletal muscles via an intravascular route is another strategy. Reports of immunity to AAV vectors delivered intravascularly have not been consistent. Studies by Gregorevic et al. (2009) documented marked inflammatory responses in dog muscle following limb artery infusion; however, the use of transient immunosuppression enhanced transgene expression. Yue et al. (2008) did not observe similar immune responses following intra-jugular injection of AAV9 into neonatal dogs, and the authors attributed this to the immature immune system in neonatal dogs. Following intravenous injection into neonatal dogs, AAV9 carrying a human mini-dystrophin, which is a potential antigen, induced inflammatory responses detected by magnetic resonance imaging at 8 weeks and by histological analysis of muscle samples at 16 weeks (Kornegay et al., 2010). Pelvic limb muscle atrophy and contractures detected at 16 weeks may be a result of the early marked inflammation responses (Kornegay et al., 2010).

In non-human primates (NHP), both humoral and cellular immunity were observed when AAV1 and AAV8 vectors were delivered intramuscularly, but not with regional i.v. injection. The immunity was not observed when animals were under immunosuppression with either mycophenolate mofetil plus prednisone for 3 weeks, or LEA29Y, a mutant of CTLA4-Ig which blocks costimulatory signaling through $\mathrm{CD} 28$ pathway that is required for optimal T cell activation (Toromanoff et al., 2008, 2010). Here, LEA29Y was expressed from AAV vector delivered intravenously to ensure therapeutic level. When LEA29Y was delivered intramuscularly, it did not eliminate immune responses to transgene product. On the other hand, no cellular immunity was observed to either AAV capsid or transgene following either intramuscular or i.v. delivery to NHP muscle by Chicoine's group (Rodino-Klapac et al., 2010). 


\section{ADMINISTRATION OF AAV TO MUSCLES OF NON-MUSCULAR DYSTROPHIES}

Muscle has also been a target for AAV-mediated gene transfer as a potential means to deliver secreted gene products to the blood for treating other genetic diseases due to easy access and muscle tropism of some AAV serotypes. Muscles in these disease models are normal comparing to the diseased muscle in muscular dystrophies. Immune responses to AAV viral capsid and/or transgene products have been reported in some studies but not in the others. In muscle-directed, AAV2-mediated canine factor IX (cFIX) transfer for treating hemophilia B in dogs, while no cellular responses were reported to either AAV2 capsid or cFIX, inhibitory anti-cFIX antibodies were reported to develop in a dose-dependent manner (Herzog et al., 1999, 2002). Transient immunosuppression with cyclophosphamide prevented anti-cFIX antibody formation and resulted in sustained transgene expression via either an intramuscular or intravascular delivery route (Herzog et al., 2001; Arruda et al., 2005, 2010). In another study by Haurigot et al. (2010), 6 weeks of immunosuppression with cyclophosphamide did not prevent the development of anti-AAV antibody and T cell infiltrates in muscle, and the T cells were transgene specific.

In human hemophilia B patients, AAV-FIX transfer to skeletal muscle did not result in therapeutic levels of FIX; however, no immune responses were observed (Manno et al., 2003). T cell responses to AAV1 capsid proteins were observed in a clinical trial for lipoprotein lipase (LPL) deficiency (Mingozzi et al., 2009). Specifically, AAV1 capsid-specific CD8 + T cells were detected at 4 weeks in half of the patients after intramuscular injection with kinetics that is dose-dependent, while no T- or B-cell responses to the LPL transgene product were seen. In a clinical trial for alpha-1 antitrypsin (AAT) deficiency (Brantly et al., 2009), humoral (by day 14) and T cell (by day 14, responses to AAV1 capsid were observed in all subjects though these immune responses did not diminish the low level of transgene expression that was observed. A recent phase II clinical trial by Flotte et al. (2011) further confirmed moderate to marked CD8 + T cell responses against AAV1 capsid protein following delivery of AAV1-AAT to muscles of patients. AAT expression was sustained but declined after day 30, and serum therapeutic AAT level was not achieved in any of the patients receiving either $6 \times 10^{11}, 1.9 \times 10^{12}$, or $6 \times 10^{12} \mathrm{vg} / \mathrm{kg}$.

\section{IMMUNE MODULATION}

The ultimate goal of AAV-mediated gene therapy is to achieve persistent transgene expression at therapeutic levels, however, at present this goal is compromised by development of de novo or amplification of pre-existing humoral or cellular host immune responses to both AAV capsid and transgene products. Preventive strategies, such as use of alternative serotypes, changes in vector dosing, route of administration, and fetal or neonatal administration may not be feasible or effective in many situations. Immune modulation designed to prevent activation and proliferation of antigen-specific T- and B-cells is more potent and may be required in addition to non-immunosuppressive preventive strategies.

Studies using AAV-based therapy coupled with immunosuppression in muscular dystrophy are limited but encouraging. In a dog model of DMD (Wang et al., 2007b), it was demonstrated that a combination of cyclosporine (CSP), a calcineurin inhibitor that impairs T cell activation; and mycophenolate mofetil (MMF), an anti-metabolite that prevents proliferation of both $\mathrm{T}$ - and $\mathrm{B}$-cells, was able to prevent immune responses to AAV in muscles of normal dogs; in dystrophic muscle which contains pre-existing and ongoing inflammation, a 5-day course of anti-thymocyte globulin (ATG) was needed in addition to a 16-week course of CSP/MMF to suppress immune responses to both AAV capsid and the canine (k9) micro ( $\mu$ )-dys transgene. More importantly, robust and prolonged expression of $\mathrm{k} 9-\mu$-dys persisted for at least 22 weeks after withdrawal of all immunosuppression. Immunosuppression by CSP and MMF also prevented cellular infiltration and led to enhanced transgene expression following intravascular delivery of AAV to muscle in dogs (Gregorevic et al., 2009). In human patients, a short course of methylprednisolone was used with LMGD and DMD (Mendell et al., 2009, 2010a), which lessened cellular responses, however, there was no transgene expression.

The generation and maintenance of immunological memory is critical for host protection when re-encountering a pathogen. However, memory cells can be a barrier in viral-mediated gene therapy for patients with muscular dystrophies who may require multiple treatments with vectors throughout life. Despite high transduction efficiency of $\mathrm{AAV}$-mediated gene transfer, readministration of AAV vectors has resulted in little or no further transduction events in tissues, such as skeletal muscle and lung. This was correlated with the appearance of viral or transgene specific neutralizing antibodies (Halbert et al., 1997). Pre-existing neutralizing antibodies or memory $\mathrm{T}$ cells specific to viral capsid protein or transgene product were also suggested to prevent sustained transgene expression in recent human trials (Kessler et al., 1996; Xiao et al., 1996; Manno et al., 2006; Mingozzi et al., 2007; Mendell et al., 2010a). However, a study on AAV delivery into lung in mice (Halbert et al., 1998) demonstrated that transient immunosuppression through blocking costimulatory signaling pathways with a combination of anti-CD40 ligand antibody and CTLA4-Ig at the time of primary AAV exposure allowed successful repeat administration of AAV to lung. More recently, Arruda and Colleagues reported that the presence of neutralizing antibodies to AAV2 did not prevent Intravascular AAV6 delivery to muscles of hemophilia B dogs given immunosuppression with cyclophosphamide 1 day prior to vector injection and weekly thereafter for 6 weeks (Herzog et al., 2001). Studies by the Wilson's group also showed sustained expression of factor IX carried by AAV8 in AAV2-pretreated hemophilia dogs (Wang et al., 2005).

\section{CONCLUSION}

Adeno-associated viral-mediated gene therapy for muscular dystrophies is a promising yet fairly complex therapeutic approach under development for approximately 20 years. The advances in the last two decades in the field are remarkable and have energized the planning and implementation of phase I clinical trials. Identification of immunity to AAV vectors emerged as a major challenge from these studies and emphasizes the importance of appropriate animal models to address safety and efficacy of the approach and predict clinical outcomes. Combining immunosuppressive therapy with other preventive strategies may be necessary to induce persistent antigen-specific tolerance in the gene therapy setting. 


\section{ACKNOWLEDGMENTS}

We thank S. Carbonneau, H. Crawford, B. Larson, K. Carbonneau, J. Fleenor, and D. Gayle for administrative assistance and manuscript preparation. This work was supported by
NIH P30-CA15704; NIH R01-AR056949; NIH R01-AR041928; NIH R37-AR40864; and by a Career Development Grant (to Z. Wang) from the Muscular Dystrophy Association (MDA 114979).

\section{REFERENCES}

Arruda, V. R., Stedman, H. H., Haurigot, V., Buchlis, G., Baila, S., Favaro, P., Chen, Y., Franck, H. G., Zhou, S., Wright, J. F., Couto, L. B., Jiang, H., Pierce, G. F., Bellinger, D. A., Mingozzi, F., Nichols, T. C., and High, K. A. (2010). Peripheral transvenular delivery of adeno-associated viral vectors to skeletal muscle as a novel therapy for hemophilia B. Blood 115, 4678-4688.

Arruda, V. R., Stedman, H. H., Nichols, T. C., Haskins, M. E., Nicholson, M., Herzog, R. W., Couto, L. B., and High, K. A. (2005). Regional intravascular delivery of AAV-2-F.IX to skeletal muscle achieves longterm correction of hemophilia B in a large animal model. Blood 105, 3458-3464.

Brantly, M. L., Chulay, J. D., Wang, L., Mueller, C., Humphries, M., Spencer, L. T., Rouhani, F., Conlon, T. J., Calcedo, R., Betts, M. R., Spencer, C., Byrne, B. J., Wilson, J. M., and Flotte, T. R. (2009). Sustained transgene expression despite $\mathrm{T}$ lymphocyte responses in a clinical trial of rAAV1-AAT gene therapy Proc. Natl. Acad. Sci. U.S.A. 106, 16363-16368.

Dudley, R. W., Lu, Y., Gilbert, R., Matecki, S., Nalbantoglu, J., Petrof, B. J., and Karpati, G. (2004). Sustained improvement of muscle function one year after full-length dystrophin gene transfer into $\mathrm{mdx}$ mice by a gutted helper-dependent adenoviral vector. Hum. Gene Ther. 15, 145-156.

Emery, A. E. (2002). The muscular dystrophies. Lancet 359, 687-695.

Flotte, T. R., Trapnell, B. C., Humphries, M., Carey, B., Calcedo, R., Rouhani, F., Campbell-Thompson, M., Yachnis, A. T., Sandhaus, R. A., McElvaney, N. G., Mueller, C., Messina, L. M., Wilson, J. M., Brantly, M., Knop, D. R., Ye, G. J., and Chulay, J. D. (2011). Phase 2 clinical trial of a recombinant adeno-associated virus vector expressing alpha 1 antitrypsin: interim results. Hum. Gene Ther. doi: 10.1089/hum.2011.053. [Epub ahead of print].

Gregorevic, P., Blankinship, M. J., Allen, J. M., Crawford, R. W., Meuse, L., Miller, D. G., Russell, D. W., and Chamberlain, J. S. (2004). Systemic delivery of genes to striated muscles using adeno-associated viral vectors. Nat. Med. 10, 828-834.

Gregorevic, P., and Chamberlain, J. S. (2003). Gene therapy for muscular dystrophy - a review of promising progress. Expert Opin. Biol. Ther. 3, 803-814.

Gregorevic, P., Schultz, B. R., Allen, J. M., Halldorson, J. B., Blankinship, M. J., Meznarich, N. A., Kuhr, C. S., Doremus, C., Finn, E., Liggitt, D., and Chamberlain, J. S. (2009). Evaluation of vascular delivery methodologies to enhance rAAV6-mediated gene transfer to canine striated musculature. Mol. Ther. 17, 1427-1433.

Halbert, C. L., Standaert, T. A., Aitken, M. L., Alexander, I. E., Russell, D. W., and Miller, A. D. (1997). Transduction by adeno-associated virus vectors in the rabbit airway: efficiency, persistence, and readministration. $J$. Virol. 71, 5932-5941.

Halbert, C. L., Standaert, T. A., Wilson, C. B., and Miller, A. D. (1998). Successful readministration of adenoassociated virus vectors to the mouse lung requires transient immunosuppression during the initial exposure. J. Virol. 72, 9795-9805.

Haurigot, V., Mingozzi, F., Buchlis, G., Hui, D. J., Chen, Y., BasnerTschakarjan, E., Arruda, V. R., Radu, A., Franck, H. G., Wright, J. F., Zhou, S., Stedman, H. H., Bellinger, D. A., Nichols, T. C., and High, K. A. (2010). Safety of AAV factor IX peripheral transvenular gene delivery to muscle in hemophilia B dogs. Mol. Ther. 18, 1318-1329.

Herson, S., Hentati, F., Rigolet, A. Romero, N. B., Behin, A., Leturcq, F., Laforet, P., Maisonobe, T., Amouri, R., Haddad, H., Audit, M., RosierMontus, M. F., Gjata, B., Masurier, C., Lemoine, F. M., Carlier, P., Hogrel, J. Y., Eymard, B., Sweeney, L., Mulligan, R., Klatzmann, D., Cherai, M., Caizergues, D., Voit, T., and Benveniste, O. (2011). A phase I dose-escalating study of AAV1- $\gamma$ sarcoglycan gene therapy for limb girdle muscular dystrophy type 2C. Mol. Ther. 19(Suppl. 1), S20-S21.

Herzog, R. W., Fields, P. A., Arruda V. R., Brubaker, J. O., Armstrong, E., McClintock, D., Bellinger, D. A., Couto, L. B., Nichols, T. C., and High, K. A. (2002). Influence of vector dose on factor IX-specific T and $B$ cell responses in muscle-directed gene therapy. Hum. Gene Ther. 13, 1281-1291.

Herzog, R. W., Mount, J. D., Arruda, V. R., High, K. A., and Lothrop, C. D. Jr. (2001). Muscle-directed gene transfer and transient immune suppression result in sustained partial correction of canine hemophilia B caused by a null mutation. Mol. Ther 4, 192-200.

Herzog, R. W., Yang, E. Y., Couto, L. B., Hagstrom, J. N., Elwell, D., Fields, P. A., Burton, M., Bellinger, D. A., Read, M. S., Brinkhous, K. M., Podsakoff, G. M., Nichols, T. C., Kurtzman, G. J., and High, K. A. (1999). Long-term correction of canine hemophilia $\mathrm{B}$ by gene transfer of blood coagulation factor IX mediated by adenoassociated viral vector. Nat. Med. 5 , 56-63.

Kessler, P. D., Podsakoff, G. M., Chen, X., McQuiston, S. A., Colosi, P. C., Matelis, L. A., Kurtzman, G. J., and Byrne, B. J. (1996). Gene delivery to skeletal muscle results in sustained expression and systemic delivery of a therapeutic protein. Proc. Natl. Acad. Sci. U.S.A. 93, 14082-14087.

Kornegay, J. N., Li, J., Bogan, J. R., Bogan, D. J., Chen, C., Zheng, H., Wang, B., Qiao, C., Howard, J. F. Jr., and Xiao, X. (2010). Widespread muscle expression of an AAV9 human mini-dystrophin vector after intravenous injection in neonatal dystrophin-deficient dogs. Mol. Ther. 18, 1501-1508.

Li, S., Kimura, E., Fall, B. M., Reyes, M., Angello, J. C., Welikson, R., Hauschka, S. D., and Chamberlain, J. S. (2005). Stable transduction of myogenic cells with lentiviral vectors expressing a minidystrophin. Gene Ther. 12, 1099-1108.

Liu, M., Yue, Y., Harper, S. Q., Grange, R. W., Chamberlain, J. S., and Duan, D. (2005). Adeno-associated virusmediated microdystrophin expression protects young $\mathrm{mdx}$ muscle from contraction-induced injury. Mol. Ther. 11, 245-256.

Manno, C. S., Chew, A. J., Hutchison, S., Larson, P. J., Herzog, R. W., Arruda, V. R., Tai, S. J., Ragni, M. V., Thompson, A., Ozelo, M., Couto, L. B., Leonard, D. G. B., Johnson, F. A., McClelland, A., Scallan, C., Skarsgard, E., Flake, A. W., Kay, M. A., High, K. A., and Glader B. (2003). AAV-mediated factor IX gene transfer to skeletal muscle in patients with severe hemophilia B. Blood 101, 2963-2972.

Manno, C. S., Pierce, G. F., Arruda, V. R., Glader, B., Ragni, M., Rasko, J. J., Ozelo, M. C., Hoots, K., Blatt, P., Konkle, B., Dake, M., Kaye, R. Razavi, M., Zajko, A., Zehnder, J., Rustagi, P. K., Nakai, H., Chew, A. Leonard, D., Wright, J. F., Lessard R. R., Sommer, J. M., Tigges, M. Sabatino, D., Luk, A., Jiang, H., Mingozzi, F., Couto, L., Ertl, H. C., High, K. A., and Kay, M. A. (2006). Successful transduction of liver in hemophilia by AAV-Factor IX and limitations imposed by the host immune response Nat. Med. 12, 342-347.

Mendell, J. R., Campbell, K., RodinoKlapac, L., Sahenk, Z., Shilling, C., Lewis, S., Bowles, D., Gray, S., Li, C., Galloway, G., Malik, V., Coley, B. Clark, K. R., Li, J., Xiao, X., Samulski, J., McPhee, S. W., Samulski, R. J., and Walker, C. M. (2010a). Dystrophin immunity in Duchenne's muscular dystrophy. N. Engl. J. Med. 363, 1429-1437.

Mendell, J. R., Rodino-Klapac, L. R., Rosales, X. Q., Coley, B. D., Galloway, G., Lewis, S., Malik, V., Shilling, C., Byrne, B. J., Conlon, T., Campbell, K. J., Bremer, W. G., Taylor, L. E., Flanigan, K. M., GastierFoster, J. M., Astbury, C., Kota, J., Sahenk, Z., Walker, C. M., and Clark, K. R. (2010b). Sustained alphasarcoglycan gene expression after gene transfer in limb-girdle muscular dystrophy, type 2D. Ann. Neurol. 68, 629-638.

Mendell, J. R., Rodino-Klapac, L. R., Rosales-Quintero, X., Kota, J., Coley, B. D., Galloway, G., Craenen, J. M., Lewis, S., Malik, V., Shilling, C. Byrne, B. J., Conlon, T., Campbell, K. J., Bremer, W. G., Viollet, L., Walker, C. M., Sahenk, Z., and Clark, K. R. (2009). Limb-girdle muscular dystrophy type 2D gene therapy restores alpha-sarcoglycan and associated proteins. Ann. Neurol. 66, 290-297.

Mingozzi, F., Maus, M. V., Hui, D. J., Sabatino, D. E., Murphy, S. L., Rasko, J. E., Ragni, M. V., Manno, C. S. Sommer, J., Jiang, H., Pierce, G. F., Ertl, H. C., and High, K. A. (2007) $\mathrm{CD} 8(+) \mathrm{T}$-cell responses to adenoassociated virus capsid in humans. Nat. Med. 13, 419-422. 
Mingozzi, F., Meulenberg, J. J., Hui, D. J., Basner-Tschakarjan, E., Hasbrouck, N. C., Edmonson, S. A., Hutnick, N. A., Betts, M. R., Kastelein, J. J., Stroes, E. S., and High, K. A. (2009). AAV-1-mediated gene transfer to skeletal muscle in humans results in dose-dependent activation of capsid-specific T cells. Blood 114, 2077-2086.

Ohshima, S., Shin, J. H., Yuasa, K., Nishiyama, A., Kira, J., Okada, T., and Takeda, S. (2009). Transduction efficiency and immune response associated with the administration of AAV8 vector into dog skeletal muscle. Mol. Ther. 17, 73-80.

Rodino-Klapac, L. R., Montgomery, C. L., Bremer, W. G., Shontz, K. M., Malik, V., Davis, N., Sprinkle, S., Campbell, K. J., Sahenk, Z., Clark, K. R., Walker, C. M., Mendell, J. R., and Chicoine, L. G. (2010). Persistent expression of FLAG-tagged micro dystrophin in nonhuman primates following intramuscular and vascular delivery. Mol. Ther. 18, 109-117.

Toromanoff, A., Adjali, O., Larcher, T., Hill, M., Guigand, L., Chenuaud, P., Deschamps, J. Y., Gauthier, O., Blancho, G., Vanhove, B., Rolling, F., Cherel, Y., Moullier, P., Anegon, I., and Le Guiner, C. (2010). Lack of immunotoxicity after regional intravenous (RI) delivery of rAAV to nonhuman primate skeletal muscle. Mol. Ther. 18, 151-160.

Toromanoff, A., Chérel Y, Guilbaud, M., Penaud-Budloo, M., Snyder, R. O., Haskins, M. E., Deschamps, J. Y., Guigand, L., Podevin, G., Arruda, V. R., High, K. A., Stedman, H. H., Rolling, F., Anegon, I., Moullier, P., and Le Guiner, C. (2008). Safety and efficacy of regional intravenous (r.i.) versus intramuscular (i.m.) delivery of rAAV1 and rAAV8 to nonhuman primate skeletal muscle. Mol. Ther. 16, 1291-1299.

Vandenberghe, L. H., Wang, L., Somanathan, S., Zhi, Y., Figueredo, J., Calcedo, R., Sanmiguel, J., Desai, R. A., Chen, C. S., Johnston, J., Grant, R. L., Gao, G., and Wilson, J. M. (2006). Heparin binding directs activation of $\mathrm{T}$ cells against adeno-associated virus serotype 2 capsid. Nat. Med. 12, 967-971.

Wang, L., Calcedo, R., Nichols, T. C., Bellinger, D. A., Dillow, A., Verma, I. M., and Wilson, J. M. (2005). Sustained correction of disease in naive and AAV2-pretreated hemophilia B dogs: AAV2/8-mediated, liver-directed gene therapy. Blood 105, 3079-3086.

Wang, Z., Allen, J. M., Riddell, S. R., Gregorevic, P., Storb, R., Tapscott, S. J., Chamberlain, J. S., and Kuhr, C. S. (2007a). Immunity to adenoassociated virus-mediated gene transfer in a random-bred canine model of Duchenne muscular dystrophy. Hum. Gene Ther. 18, 18-26.

Wang, Z., Kuhr, C. S., Allen, J. M., Blankinship, M., Gregorevic, P., Chamberlain, J. S., Tapscott, S. J., and Storb, R. (2007b). Sustained AAV-mediated dystrophin expression in a canine model of Duchenne muscular dystrophy with a brief course of immunosuppression. $\mathrm{Mol}$ Ther. 15, 1160-1166.

Wang, Z., Storb, R., Lee, D., Kushmerick, M. J., Chu, B., Berger, C., Arnett, A., Allen, J., Chamberlain, J. S., Riddell, S. R., and Tapscott, S. J. (2010). Immune responses to AAV in canine muscle monitored by cellular assays and non-invasive imaging. Mol Ther. 18, 617-624.

Xiao, X., Li, J., and Samulski, R. J. (1996). Efficient long-term gene transfer into muscle tissue of immunocompetent mice by adeno-associated virus vector. J. Virol. 70, 8098-8108.

Yuasa, K., Yoshimura, M., Urasawa, N., Ohshima, S., Howell, J. M., Nakamura, A., Hijikata, T. Miyagoe-Suzuki, Y., and Takeda, S. (2007). Injection of a recombinant AAV serotype 2 into canine skeletal muscles evokes strong immune responses against transgene products. Gene Ther. 14, 1249-1260.

Yue, Y., Ghosh, A., Long, C., Bostick, B., Smith, B. F., Kornegay, J. N., and Duan, D. (2008). A single intravenous injection of adenoassociated virus serotype- 9 leads to whole body skeletal muscle transduction in dogs. Mol. Ther. 16, 1944-1952.

Conflict of Interest Statement: The authors declare that the research was conducted in the absence of any commercial or financial relationships that could be construed as a potential conflict of interest.

Received: 15 July 2011; paper pending published: 11 August 2011; accepted: 07 September 2011; published online: 26 September 2011.

Citation: Wang Z, Tapscott SJ, Chamberlain JS and Storb R (2011) Immunity and $A A V$-mediated gene therapy for muscular dystrophies in large animal models and human trials. Front. Microbio. 2:201. doi: 10.3389/fmicb.2011.00201

This article was submitted to Frontiers in Microbial Immunology, a specialty of Frontiers in Microbiology.

Copyright (ㅇ 2011 Wang, Tapscott, Chamberlain and Storb. This is an open-access article subject to a nonexclusive license between the authors and Frontiers Media SA, which permits use, distribution and reproduction in other forums, provided the original authors and source are credited and other Frontiers conditions are complied with. 